\title{
ABORTO EUGÊNICO: IMPOSSIBILIDADE DE SELEÇÃO DO FETO
}

Evelyn Pereira da Silva

Universidade do Oeste Paulista - UNOESTE, curso de Direito, Presidente Prudente, SP. E-mail: evelyn1.pereira@hotmail.com

\section{RESUMO}

O presente trabalhobusca realizar, de forma pormenorizada, uma analise sobre o aborto eugênico e alertar a sociedade de tamanha atrocidade que consiste o aborto de fetos com a anomalia, sendo possível a vida extrauterina. Consiste também em elencar, que a vida é um bem que embora relativo,deve ser respeitado, pois, está consagrado em nossa Constituição e significa que uma é garantia fundamental.A metodologia constou de pesquisas bibliográficas. Os dados obtidos foram analisados utilizando-se do método hipotético dedutivo.A temática aqui abordada leva a sociedade a uma reflexão sobre como deve ser visto o aborto eugênico, os motivos e as soluções, para que ele exista. Visa principalmente a abordar uma questão de humanização, já que não existe previsão legal, e a levar essa apresentação ao âmbito social, para que seja debatida e abordada no campo da ilegalidade.

palavras-chave: Aborto;Eugênico; Impossibilidade; feto; anomalia

\section{EUGENIC ABORTION: IMPOSSIBILITY OF FETAL SELECTION}

\section{ABSTRACT}

This paper seeks to carry out, in detail, an analysis on abortion and eugenics society from such atrocity that is the abortion of fetuses with the anomaly, being possible to extrauterina life. Is also in list, that life is a well that although relative, must be respected, therefore, is enshrined in our Constitution and means that $a$ is fundamental guarantee. The methodology consisted of bibliographical research. The data obtained were analyzed using the hypothetical deductive method. The theme discussed here leads to a reflection on how society should be seen the abortion, eugenics and the solutions so that it exists. Aims mainly to address a matter of humanizing, since there is no legal provision, and take this presentation to the social sphere, to be debated and addressed in the field of illegality.

keywords:Abortion;Eugenic;Impossibility;fetus; anomaly

\section{INTRODUÇÃO}

Atualmente se busca através da ciência o corpo perfeito, aquele que não se podem encontrar deformidades. E é por meio da Eugenia que se busca eliminar essas anomalias em seu verdadeiro princípio, o ventre, formulando o que denominamos de "Aborto Eugênico". Observa-se que hádiferenças do aborto eugênico, do aborto nos casos de anencefalia (permitidos pelo STF), tendo em vista a possibilidade deste tipo de abordo por questões além da estética.

O termo "Eugenia" foi um pensamento difundido pelo britânico Francis Galton no século XIX e que posteriormente se disseminou em outros países, sendo um deles o Brasil na década de 1910, com o médico Renato Ferraz, no qual suas considerações eram de seleção de fetos que não possuíam defeitos, para o melhoramento da raça humana.

Levando esse parecer ao âmbito jurídico, podemos observar que atualmente o aborto é um 
meio para tal seleção humana de fetos, buscando eliminar aqueles indesejáveis.

Em nosso Código Penal, tal conduta está tipificada nos artigos 124 a 126, ou seja, constitui crime contra a vida, ou melhor, contra a vida humana intrauterina. Assim, a eugenia possui um caráter totalmente discriminatório e juntamente com o aborto uma índole ilícita.

O aborto eugênico na maioria das vezes é uma opção dos genitores que, ao descobrirem que o embrião possui anomalias, buscam interromper a gravidez para que no posterior nascimento não haja problemas sócias e características antipatizantes.

Contudo, como não há lei especifica sobre o tema abordado, serão analisados ao longo da pesquisa alguns pensamentos doutrinários e jurisprudenciais, visto que este assunto é de suma importante nos dias de hoje, principalmente, no âmbito social.

\section{METODOLOGIA}

O presente artigo foi desenvolvido com a coleta de jurisprudências e por meio de fichamentos das posições doutrinárias. De característica conceitual e introspectiva, apresenta peculiaridades de pesquisa qualitativa, visto que, esta amparado por artigos eletrônicos, julgados e livros.

Portanto, apresenta o método hipotético dedutivo, partindo das bibliografias - textos jurídicos - para a delimitação de um particular. Assim, pretende-se com o presente estudo, apresentar critérios para entender a impossibilidade da prática do aborto eugênico, tendo em vista que o direito à vida é um dos direitos fundamentais mais elementares, caracterizando os demais direitos, inferiores à própria vida.

\section{DISCUSSÃO}

\section{ORIGEM HISTÓRICA}

Previamente, a eugenia é a ciência que progrediu com anseio para a busca de homens ideais, afim de que se atinja uma sociedade pura e perfeita.

Sabe-se que os eugênicos acreditavam que deveria ser eliminado qualquer tipo de ser que possuísse deficiências morais ou físicas, posto que isto diminuísse os problemas sociais, principalmente o assistencialismo por parte do Estado.

Para Pessini e Barchifontaine (2000, p. 234):

Pode-se dizer que aborto é a expulsão ou extração de toda ou parte da placenta ou membranas, que não tenha um feto identificável, ou até mesmo com um recém-nascido vivo ou morto que tenha por peso menos de quinhentos gramas. Caso não consiga se identificar o peso, pode se ter a gestação por uma estimativa de menos de vinte semanas completas a contar-se do primeiro dia do último período menstrual normal.

Vários países foram atingidos por essas ideias, entre eles os Estados Unidos, a Suécia e, sobretudo as ações de Hitler, na antiga União soviética.

Os milhões de mortos pelos regimes totalitários do século XX eram vistos como indignos à luz das doutrinas racistas ou revolucionárias de seus algozes para suspeitar que exista algum tipo de incompatibilidade entre dignidade humana e manipulação genética, quer autoritária, quer liberal. (HECK, 2006, p. 44).

No século XX as tais convicções chegaram à América Latina, e ao que condiz ao Brasil os ideais foram difundidos por Renato Kehl Ferraz. Segundo os cientistas, para que houvesse tal seleção, eram utilizados métodos e testes de inteligência (QI), medição do crânio e dos corpos com o objetivo de uma esterilização social:

Renato Kehl, um dos maiores representantes do movimento eugênico brasileiro, afirmava que, para salvar o país, seria necessário adotar alguns procedimentos tais como: esterilização compulsória e permanente, controle de casamentos e educação eugênica. Inteligência, vocação, 
talentos e demais características são hereditários. (cf. BOARINI, 2003).

Contudo essas ideias foram levadas mais intensamente ao fato da gestação, pois a esterilização social seria mais facilmente adquirida se o feto nem viesse a viver. Portanto essas ideias foram disseminadas, e em virtude dessas deformações muitas gestantes utilizavam a substância "thalimodime", para praticar o aborto.

\section{CONCEITO E DEFINIÇÃO}

Ao falarmos mais precisamente do Aborto eugênico, tem-se que este se caracteriza como uma pré-seleção humana que dispõem do intuito de evitar os riscos de uma gestação de embriões deficientes. Percebe-se que desde os tempos mais primitivos os homens buscam fazer sua preferência pelos melhores animais e pelos melhores frutos.

Mas será que podemos selecionar um bem tão precioso quantoa vida?

Sabe-se que foi por este motivo que muitas atrocidades foram cometidas, e, no entanto, surgiram os problemas que envolvem questões econômicas e sociais. Com o progresso da medicina foram criados inúmeros diagnósticos, um deles o pré-implantatório que identifica de imediato o gene defeituoso, e o pré-natal que diagnostica o feto no ventre materno e que analisa a possível enfermidade. Ao atinar que feto tem tal anomalia, alguns genitores buscam o descarte, caracterizando o que chamamos de abortamento eugênico.

A técnica do pré-implantório analisa o embrião antes de este estar implantado no útero, sendo este método utilizado de 8 a 10 células e diagnostica se o feto possui alguma doença genética ou hereditária, assim possibilitando a opção dos pais de descartarem o embrião que possui deficiências.

De acordo com Sgreccia (2002, p. 258):

São duas as justificativas éticas utilizadas para quem pratica o diagnóstico pré-implantatório. A primeira é que se pretende prevenir o nascimento de um ser doente e por este motivo não haveria a necessidade de se fazer um aborto num estágio pós-implante, o objetivo aqui é conhecer eventuais defeitos ou anomalias. A segunda é a de responder a um anseio do casal, o qual tem preferência por um determinado sexo. Além destas duas pseudojustificativas existe a tentativa experimental buscada com muito afinco na fase de pré-implante.

Já no pré-natal, é retirado o material do feto após este estar no útero, se baseando em analisar mais precisamente as doenças graves, entre elas sua má formação.

O diagnóstico pré-natal visa a detecção de enfermidades geradas por alterações hereditárias, mediante o emprego de técnicas que incidem sobre a pessoa no seu estágio fetal, durante a vida intrauterina, com o escopo de salvar a sua vida, instaurando uma terapia gênica, respeitando sua integridade e dignidade e procurando eliminar ou diminuir os efeitos do gene anormal de que é portadora (DINIZ, 2001, p. 379).

Nota-se que com estes e outros inúmeros meios de análise é possível tornar eficaz o que chamamos de eugenia negativa, que compreende a esterilização e o controle de fetos.

Desta forma, far-se-á a análise da problemática ao que tange a falta de legislação específica ao aborto eugênico, ficando os juristas sob noções da própria constituição e do código penal vigente.

\section{PREVISÃO NORMATIVA}

O Direito penal Brasileiro consagra em sua legislação os abortos em modo genérico, ao instituir um tipo objetivo que descreve qualquer ação produzida para interromper a morte do feto. Todavia, a legislação se demonstra lacunosa ao abranger o tema do aborto eugênico. Vejamos o que dispõe o nosso Código Penal (1940):

Aborto provocado pela gestante ou com seu consentimento 
Art. 124 - Provocar aborto em si mesma ou consentir que outrem Iho provoque:

Pena - detenção, de um a três anos.

Aborto provocado por terceiro

Art. 125 - Provocar aborto, sem o consentimento da gestante:

Pena - reclusão, de três a dez anos.

Art. 126 - Provocar aborto com o consentimento da gestante:

Pena - reclusão, de um a quatro anos.

Parágrafo único. Aplica-se a pena do artigo anterior, se a gestante não é maior de quatorze anos, ou é alienada ou débil mental, ou se o consentimento é obtido mediante fraude, grave ameaça ou violência

Forma Qualificada

Art. 127 - As penas cominadas nos dois artigos anteriores são aumentadas de um terço, se, em consequência do aborto ou dos meios empregados para provocá-lo, a gestante sofre lesão corporal de natureza grave; e são duplicadas, se, por qualquer dessas causas, lhe sobrevém a morte.

Nota-se que o Código Penal Brasileiro adotou o sistema de indicações, ou seja, a vida do nascituro é um bem jurídico digno de proteção penal.

A legislação pátria aceita como forma de exclusão de ilicitude somente duas indicações: a indicação terapêutica, que é consequência da gravidez de risco para gestante, e a indicação sentimental onde a gravidez é resultado de um crime de natureza sexual. (PRADO, 2010, p. 93-94).

Ainda assim, não há em que se falar em excludente de ilicitude ao afirmar um abortamento eugênico, pois existem inúmeros casos em que o feto, mesmo com suas anomalias, conseguiria viver por meses e anos. Pelos prognósticos dos médicos compreende-se que bebês com Síndrome Edwards sobrevivem de 2 a 3 meses para os meninos e 10 meses para as meninas, portanto, devese salvar o bem jurídico que é a vida.

As únicas hipóteses elencadas de abordo legal em nosso código penal, que se equiparam as excludentes de ilicitude, são as previstas no artigo 128.

Na primeira hipótese existe o aborto necessário, que é o estado de necessidade, pelo qual o médico tem o único meio de salvar a vida da gestante. Já a segunda hipótese resulta da gravidez fruto de um crime sexual (estupro), onde o aborto somente será precedido pelo consentimento da gestante ou de seus responsáveis em caso de incapacidade.

Porém, a Carta Magna em 1988 consagrou em seu artigo 5으, precisamente em seus incisos III e $\mathrm{X}, \mathrm{O}$ que nos leva a afirmar que este tratamento abortivo é desumano e totalmente degradante, consequentemente violando a vida,sendo esta um dos bens mais preciosos advindos dos direitos e garantias fundamentais.

Tessaro (2008),explica que por tamanha atrocidade é inexplicável a falta de legislação específica no Brasil. De fato, não existe ainda um parecer sobre o aborto realizado em fetos com anomalia fetal grave.

Não obstante, é a partir das doutrinas que temos um parecer mais especifico do aborto eugênico. Maria Helena Diniz (2001, p. 34) assim ensina:

[...] interrupção criminosa da gestação quando: houver suspeita de que, provavelmente, o nascituro apresenta doenças congênitas, anomalias físico-mentais graves, como microcefalia, retinite pigmentosa, sífilis, mongolismo epilepsia genuína, demência precoce, idiotia amaurótica etc.; o embrião não pertencer ao sexo almejado. É o praticado, portanto, com o escopo de aperfeiçoar a raça humana, logrando seres geneticamente superiores ou com caracteres genéticos predeterminados para alcançar uma forma depurada de eugenia, que substitui o direito de procriar pelo de nascer com maiores dotes físicos. Está vedado legalmente, pois toda seleção eugenésica, ou não, contraria a natureza ética da procriação, ferindo a dignidade humana. Além 
disso, não há diagnóstico genético que garanta, com toda certeza, a transmissibilidade de deficiências físico-mentais, e ninguém poderia prever quais os caracteres mais úteis para humanidade, porque o homem vale pelo que é e não pelo seu aspecto físico.

Atualmente as únicas garantias existentes são os próprios artigos legislativos sobre o aborto, enquanto há um avanço estupendo na medicina fetal, estamos estagnados nos conceitos legislativos.

\section{CONCLUSÃO}

Todos têm como garantia o direto a vida, sendo em sua primeira acepção a garantia de permanecer vivo, pois o feto já se constitui um ser individualizado, e o fato de apresentar algumas anomalias não retira esse direito concedido pela Constituição e pelo Código Civil, resguardado o direito ao nascituro no artigo 2 ‥

Comumente o aborto eugênico vem sendo aderido por muitos genitores para cessar a possível imperfeição dos fetos. Sabe-se que os meios de diagnósticos são inexpressivos e acabam reafirmando a única percepção que vem dos pais.

Por se tratar de vida, este é um bem que compromete toda a sociedade e inclusive o Estado. Alguns debates estão sendo iniciados, e já são temas de jurisprudências neste sentido.

Porém, as lacunas existentes no momento levam a severos e divergentes entendimentos. $\mathrm{O}$ descarte de novos seres deve ser bem analisado, por corresponder à vida de um ser humano. Afinal a dignidade da pessoa humana deve ser respeitada, e não medida por padrões físicos e mentais.

Em suma, por ser deplorável a falta de legislação peculiar, na prática é de se deparar com divergências judiciais ao que tange ao assunto abordado, pois há juízes que procedem ao aborto em caso de eugenia, outros, entretanto, entende ser improcedente tal pedido, ao reafirmarem as lacunas na legislação vigente.

\section{REFERÊNCIAS}

BRASIL. Constituição (1988). Constituição da República Federativa do Brasil. Brasília: Senado Federal, 1988.

CAPEZ, F. Curso de Direito Penal. 15 ed. São Paulo: Saraiva, 2015;

GRECO, R. Curso de Direito Penal. 12 ed.Niterói: Impetus,2015;

BITENCOURT, C. Tratado de Direito Penal. 3 ed. São Paulo: Saraiva, 2003;

PRADO, L. Curso de Direito Penal Brasileiro. 8 ed. São Paulo: Revista Tribunais, 2010;

DELMANTO, C., Código de Direito Penal Comentado. 6 ed. Rio de Janeiro: Renovar, 2002;

SGRECCIA, E.Manual de bioética. Tradução:Orlando Soares Moreira. 2 ed.São Paulo: Loyda,2002;

NUCCl, G. Código Penal comentado, 16 Ed. São Paulo: Forense, 2016;

MASON, C. Código Penal comentado. 2ed.São Paulo: Forense,2014;

FUHRER, M. Código Penal comentado. 3 ed. São Paulo: Malheiros, 2010; 
DINIZ, M. O Estado atual do biodireito. 9 ed. São Paulo: Saraiva, 2014;

TESSARO, A. Aborto seletivo. 2 ed. São Paulo: Revista e atualizada, 2008;

AMARAL, J. As lacunas da lei e as formas de aplicação do Direito.Disponível em: <HTTPS://jus.com.br/artigos/30/as-lacunas-da-lei-e-as-formas-de-aplicacao-do-direitoJornal>. Acesso em: 01 mar 2016.

Declaração Universal dos Direitos Humanos. Disponível em: <http://portal.mj.gov.br/sedh/ct/legis_intern/ddh_bib_inter_universal.htm>. Acesso em: 05jun de 2015. 